Jurnal Lakon, 5 (1) 2016

(45-52)

\title{
MELAMPAUI REZIM OPTIC: PANDANGAN YANG MENUBUH DAN EROTISME ALICE EVE DALAM “STARTER FOR 10"1
}

Beyond Optical Regime : Haptic Vision and Eroticism of Alice Eve in "Starter for 10"

\author{
GHANESYA HARI MURTI \\ Program Studi Magister Kajian Sastra dan Budaya \\ Fakultas Ilmu Budaya Universitas Airlangga \\ Jl. Dharmawangsa Dalam Selatan, Surabaya 60286 \\ e-mail: ghanesyaharimurti@yahoo.co.id
}

\begin{abstract}
Cinematic capability in the movie "Starter For 10" is to remind that eroticism or intimacy is able to surpass the optical regime or gaze as initiated by Mulvey"s feminist film theory. Deleuze purposes haptic vision, which later on developed by Marks into Haptic Visuality as cinematic ability to dismantle subject-object relation within Mulvey"s idea that assumed women body only as pleasure. Eroticism offered in the film is able to perform haptic visuality where the audience has a sense of being touched when the eye is no longer able to accommodate the information and the optical has loss its control. Haptic vision allows both to be object because the sensations move to the other senses. Thus, Alice Eve is not only an object but also invites the audience to be the object as well when the other senses are active. Eroticism presented in the film is no longer busy looking for subject and object but more into a unity where deterministic category is no longer exist.
\end{abstract}

Keywords: Haptic Vision, Haptic Visuality, Pleasure, Optics, Subject-Object

Abstrak: Kapabilitas sinematis dalam film "Starter For 10" adalah untuk mengingatkan bahwa erotisme atau keintiman mampu melampaui rezim optik atau pandangan seperti yang diprakarsai oleh teori film feminis Mulvey. Deleuze menggunakan Haptic Vision, yang kemudian dikembangkan oleh Marks menjadi Haptic Visuality sebagai kemampuan sinematis untuk membongkar hubungan subjek-objek dalam gagasan Mulvey yang menganggap tubuh wanita hanya sebagai kesenangan. Erotisisme yang ditawarkan dalam film ini mampu menunjukkan visualitas yang menubuh di mana penonton merasa disentuh ketika mata tidak lagi dapat menampung informasi dan optik kehilangan kontrolnya. Haptic Vision memungkinkan keduanya menjadi objek karena sensasi bergerak ke indera lainnya. Dengan demikian, Alice Eve bukan hanya sebuah objek tetapi juga mengajak penonton untuk menjadi objek juga ketika indera lainnya aktif. Erotisme yang disajikan dalam film ini tidak lagi sibuk mencari subjek dan objek, tetapi lebih ke kesatuan di mana kategori deterministik tidak lagi ada.

Kata-kata Kunci: Pandangan yang Menubuh, Haptic Visuality, Kesenangan, Optik, Subjek-Obje

1Tulisan ini diilhami oleh kuliah umum, seri Kuliah Teori yang diselenggarakan oleh Fakultas Ilmu Budaya, Universitas Gadjah Mada, Yogyakarta, 31 Maret 2015, 08.00-10.00. yang diampu oleh Budi Irawanto

Jurnal Lakon: Kajian Sastra dan Budaya

e-ISSN: 2527-4899; p-ISSN 2252-8954 


\section{PENDAHULUAN}

Tak dapat dipungkiri, kehadiran aktris cantik sekelas Alice Eve dalam film menjadi daya tarik tersendiri bagi penikmat film. Seolah menjadi ritus yang sah dalam pengambilan gambar, teknik pengambilan gambar selalu berusaha menampakan pesona kecantikan sang aktris dengan berbagai macam cara. Alice Eve yang dikenal dengan kecantikan dan keseksiannya seolah tak bisa luput dari sorotan kamera dalam berbagai adegan yang menonjolkan sensualitas tubuhnya. Seperti dalam film "Starter for 10" aktris berambut pirang ini dipasangkan dengan aktor James Mc Avoy dimana dia berperan sebagai seorang mahasiswi yang akan mengikuti tes seleksi untuk mewakili kampus dalam acara "cerdas cermat" di salah satu stasiun televisi. Kemunculan awal aktris Alice Eve didalam ruang tes ditandai dengan menangkap bagian tubuh tertentu dari tubuh sang aktris yang dinilai sensual seperti paha, tengkuk dan bagian tubuh lain dari kacamata aktor, James Mc Avoy, yang seolah "menelanjangi" kehadiran sang aktris. Pada hemat khusus, salah satu tekhnik kamera, seperti montage pada dasarnya menekankan unsur estetik sebagai usaha menangkap realita.

Teknik kamera yang memadukan tokoh, posisi, pencahayaan, desain tempat, fokus dan lainnya secara ideal merupakan usaha untuk menampilkan ilusi realitas yang berujung pada seni (Turner, 1999:42). Namun pada kasus Alice, realita dalam kamera tidak selalu berorientasi pada segi estetis semata tapi juga eksplotatif yang selektif dalam melihat isu - isu feminitas. Terlebih ilusi realita yang diidealkan sebagai seni bukanlah sesuatu yang otomatis dan netral melainkan penuh kontrol untuk memunculkan sensasi tertentu pada penonton. Kontrol yang pada diri penonton dimungkinkan untuk memunculkan momen kontemplasi erotis ketika kehadiran wanita seolah membuka gerak aksi (Mulvey, 2006:165)

Disisi lain, sebagai praktik kesenian, teknik montage melihat kesatuan gambar/suara diharapkan dapat menstimulus emosi tertentu atau respon kognitif (Sandra et all, 2006:150). Sebagai contoh, seperti halnya ketika gambar wajah kemudian dilanjutkan dengan gambar potongan roti, akan menampilkan citra lapar melalui kombinasi shots (Turner, 1999:37). Berbeda dengan contoh tersebut, citra erotisme yang muncul dalam adegan yang diperankan oleh Alice, tentunya tidak hanya berakhir pada sensasi stimulus secara kognitif hasil dari produksi indra penglihatan. Erotisme Alice Eve memungkinkan munculnya efek lain dalam perilaku penonton karena bisa saja kegiatan mata yang tak berkedip, beralih menjadi kegiatan seperti mengecap lidah, merasakan tekstur, dan bahkan membayangkan sensasi kulit lembut sang aktris. Maka ada usaha pengaktifan aspek indera lain ketika momen kontemplasi erotis terjadi. Deleuze melihat gambaran respon ini sebagai sebuah proses penglihatan yang menubuh atau yang dia sebut dengan haptic vision.

"Haptic" vision and close viewing, it is not merely visual but refers to tactile values, even though it still subordinates them to vision. In fact, what replaces haptic space is a tactile-optical space, in which what is expressed is no longer essence but connection; that is, the organic activity of man. (Deleuze, 2003:126) 
Haptic vision atau pandangan yang menubuh adalah istilah yang digunakan oleh Deleuze untuk menjabarkan kemampuan mata ketika memandang objek pada derajat tertentu akan mampu mengaktifkatan indera yang lain (tactile). Jika indera penglihatan diakui sebagai unsur penting dalam menikmati film ternyata ada usaha eksplorasi atas indra lain yang bermain dalam menghayati film, ketik adegan erotis hanya dimaknai sebagai visual pleasure. Maka tulisan ini dimaksudkan untuk memberikan penjelasan lebih lanjut secara teoritik fenomena audien baik dari segi feminis ala Mulvey dan pandangan haptic yang diawali oleh Deleuze lalu dikembangkan secara sistematik oleh Marks. Pemikir dan teoritisi film ini diharapkan mampu memberikan penjelasan yang lebih rigoris mengenai perilaku penonton di momen kontemplasi erotis baik secara efek atas sensasi kulit maupun tatapan yang seolah "menelanjangi".

Menilik kompleksitas momen erotis dalam respon penonton baik sebagai visual pleasure maupun stimulus bagi aktifnya indera non optic, dapat disimpulkan rumusan masalah yaitu bagaimana haptic vision dan spectator"s gaze bekerja dalam film "Starter for 10" yang diperankan oleh Alice Eve dan James Mc Avoy. Dalam hal ini indera non optic yang dimaksud adalah peraba (tactile).

\section{LANDASAN TEORI}

\section{Haptic Vision, Tatapan yang Meraba Feminitas}

Bas-relief brings about the most rigid link between the eye and the hand because its element is the flat surface, which allows the eye to function like the sense of touch; furthermore, it confers, and indeed imposes, upon the eye a tactile, or rather haptic, function...It is a frontal and close view that assumes this haptic function, since the form and the ground lie on the same plane of the surface, equally close to each other and to ourselves. (Deleuze, 2003:122-123)

Deleuze pada awalnya sangat tertarik pada kemampuan gambar yang sangat memungkinkan fungsi mata layaknya seperti indera peraba ketika melihat permukaan relief. Permukaan relief yang cenderung kasar seolah memberikan informasi lebih pada mata sehingga mampu mengaktifkan fungsi indera peraba karena hilangnya batas antara objek dan pengamat. Haptic vision kemudian digunakan sebagai pandangan yang menubuh, menubuh dalam artian pada terbukanya potensi indera lain untuk ikut memahami gambar seperti halnya indera peraba. Syarat penting yang membuat objek dapat ditangkap secara haptic vison adalah warna - warna, sehingga kreatifitas pewarnaanlah yang menyusun haptic (Deleuze, 2003:152-153). Terlihat jelas keseriusan pemikiran Deleuze untuk memisahkan level awal sebagai optical code yang hanya menjadi referensi virtual (tactical referent) yang mensubordinasi peraba, namun ketika mata terbawa pada dimensi tanpa bentuk dan pergerakan tanpa akhir mata tidak lagi mampu mengimbangi dan menangguhkan fungsi optic, pada akhirnya Deleuze melihat relasi pembalik ini sebagai pekerjaan tangan, atau hilangnya kontrol mata saat penglihatan menemukan dirinya sebagai sebuah fungsi spesifik peraba, yang berbeda dari fungsi alamiahnya secara optic (Deleuze, 2003:152-155). Tradisi pemikiran Deleuze kemudian mengilhami Laura U. Marks untuk menjabarkan secara lebih rigoris tentang fungsi haptic untuk 
memahami film. Marks menawarkan teori haptic visuality, dimana visualitas bisa berfungsi sebagai indera peraba. Beberapa jenis film menggunakan imaji haptic untuk menawarkan penonton sensasi yang seolah memebangkitkan indera peraba, atau touch (Marks, 200:22). Terlihat jelas bahwa Marks membedakan secara lebih jelas fungsi haptic, menjadi haptic visuality (sensasi indera peraba) dan haptic images (imaji haptic dalam film yang merangsang perabaan penonton sebagai pengalaman yang berdasar pada sentuhan). Pada level ini analisis adegan akan mulai diberi perhatian khusus, melalui teknik kamera yang tentunya selalu berupaya menciptakan haptic images.

\section{METODE PENELITIAN}

Secara metodis uraian jalur
pemikiran tentang pandangan yang
menubuh adalah usaha memetakan posisi
kekuasaan melalui tatapan. Namun
kekuasaan disini bukanlah kekuasaan yang
diandaikan melalui hubungan subjek-objek
seperti yang diandaikan oleh Laura Mulvey
dimana Gaze menjadi pemuas hasrat
patriarkis seperti beberapa diskursus film
(Mulvey,1996:42), melainkan adalah upaya
penghilangan unsur subjek-objek ketika
disajikan dalam teknik kamera yang
memunculkan kualitas haptic atau
hilangnya kontrol mata sehingga
memberikan afeksi pada indera yang lain.
Pemikiran ini akhirnya memetakan
kekuasaan bukan berada mutlak pada
penonton "power (what Nietzsche calls „will
to power" and Welles, "character") is this
power to affect and be affected, this relation
between one force and others” (Deleuze,
1989:139). Artinya kekuasaan hadir ketika
diri rela mengafeksi sekaligus diafeksi
sehingga pemilahan antara subjek dan

objek seperti yang diandaikan Mulvey menjadi hilang.

Walaupun begitu secara metodis uraian teoritis tadi akan diawali dengan yang pertama yaitu penentuan relasi subjek objek secara biner. Mulvey mengambil posisi kamera adalah selalu memiliki kelamin yakni maskulin sebagai yang aktif dan yang voyeuristic sedangkan objek gambar wanita adalah yang pasif sekaligus eksibisionis (Mulvey,1996:62). Maka dipilihlah aktris Alice Eve dan James Mc Avoy yang dalam film dikesankan memiliki relasi tersebut. Mc Avoy secara tidak langsung menjadi aktor yang mengakomodir bahwa sudut pandang kamera secara dominan menjadi berkelamin maskulin.

Kedua, tahapan selanjutnya adalah pemilihan adegan yang memunculkan kesan erotis, maka dipilihlah adegan yang paling memiliki potensi memunculkan diskursus mengenai gaze, dan adegan tesebut adalah dimana aktris Alice Eve datang terlambat pada saat tes. Keseluruhan shot dalam adegan tes tulis tersebut dibingkai pada teknik kamera sebagai hal yang penting untuk menentukan relasi hubungan yang ingin disuguhkan kepada penonton sekaligus memunculkan performance art (Turner,1999:60).

Ketiga, keseluruhan adegan tersebut dianggap penting karena posisi kamera menyuguhkan relasi aktor pria James Mc Avoy untuk menaklukkan citra Alice Eve sebagai the other justru gagal ketika relasi gaze terjadi. Perlu diketahui konsep erotis disini adalah konsep intersubjektif erotis milik Marks yang secara tegas menyatakan adanya mutual recognizition antara beholder dan work cinema dimana relasi 
subjek objek menjadi hilang ketika momentum erotis terjadi, artinya relasi erotis diandaikan pada keintiman dimana gambar menyapa balik penonton sehingga jarak antara gambar dan penonton menjadi hilang karena diri "menyerah" pada hasrat akan gambar (Marks, 2000:183).

\section{PEMBAHASAN}

\section{Menyoal Feminitas dalam Kamera dan Seni yang Melampaui Tatapan}

Teknik kamera berusaha memberikan kesan kuasa ketika kamera melihat subjek dengan arah kebawah (Turner, 1999:60), hal ini terlihat jelas pada adegan dimana Alice hendak duduk di bangkunya, kamera seolah memberikan kesan dan nuansa penuh kontrol pada subjek, yaitu James Mc Avoy.

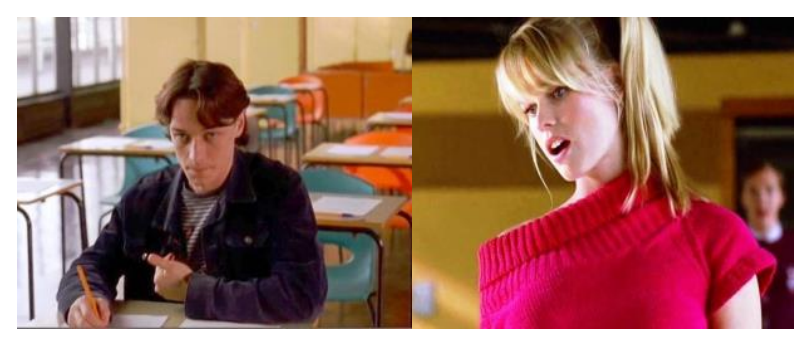

Teknik ini yang kemudian berusaha untuk melibatkan intensi dari kamera dalam menjabarkan relasi kuasa antara Alice dan James secara slow motion, dimana pada wilayah grammar film dimaknai sebagai penaklukkan atas subjek. Namun dalam hemat feminitas ini merupakan wilayah hilangnya relasi antara dua tokoh yang berlanjut pada penonton untuk menatap. Mulvey melihat ini sebagai upaya akomodasi "fetishistic spectator" yaitu kritik peralihan dimana unsur naratif tidak lagi menjadi hal yang penting, melainkan keterlibatan dari penonton untuk menatap (Mulvey, 2006:165). Kerja kamera tidak selesai pada wilayah kuasa tapi jauh kedalam batas sensasi yang sebisa mungkin bisa muncul dalam deret gambar seperti yang ditampilkan sebagai berikut.

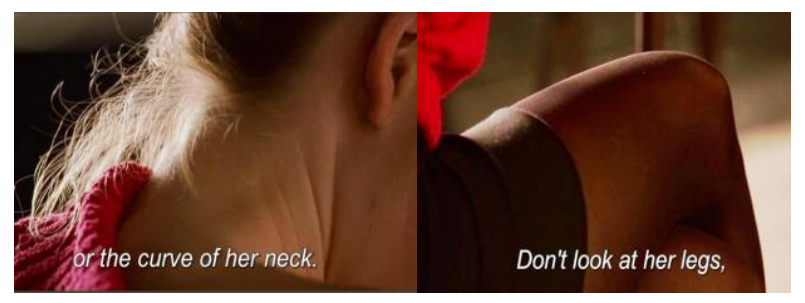

Menatap bersifat inderawi ataupun kognitif tapi juga sangat mungkin berusaha membebaskan indera lain yaitu haptic untuk masuk dan merasakan betul tekstur lembut yang ditampilkan oleh kecanggihan kamera dalam mengambil detail gambar, seperti lipatan kulit, bulu tengkuk, dan lipatan paha yang semuanya merujuk pada haptic images. Erotisme bekerja disini, Marks mengutarakan erotisme bagi Marks, khususnya dalam wilayah seks adalah hilangnya batasan antara yang menerima dan yang memberi (Marks, 2002:xvi). Usaha melihat tengkuk dan paha Alice kini beralih dari rezim penglihatan menjadi rezim inderawi lain, yang menurut Marks memberikan peluang terbukanya visualitas tentang apa yang berjarak dan menubuh, yang optic dan juga haptic, sehingga kuasa tidak sepenuhnya pada mata tapi sensori lain (Marks, 2000:132).

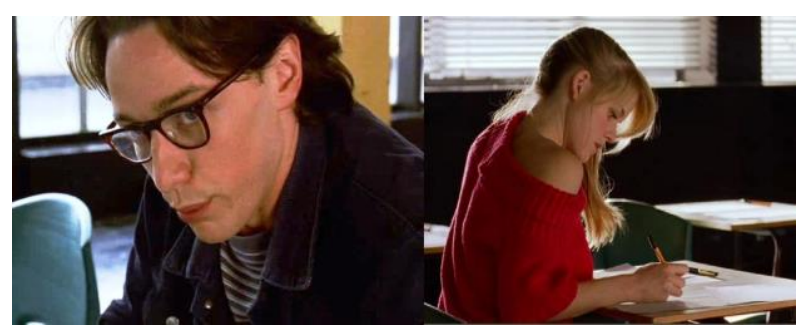

Erotisme dalam pandangan Marks tidak bisa diartikan secara harfiah, karena erotis adalah kemampuan menjadi objek bersama dan bagi dunia (film) lalu kembali menjadi subjek dalam dunia fisik 
(corporeal), sehingga erotis tidak selalu berhubungan dengan seks (Marks, 2003:xvi). Berbeda dengan Mulvey, proses menghela nafas Mc Avoy dan mengintip tengkuk Alice adalah erotisme murni yang merujuk pada konsep voyeurism dan legitimasi atas kamera yang memiliki kelamin (pria), terlihat dari pemilihan sinematis seperti point of view, dimensi layar dan lainnya yang sangat maskulin (Mulvey, 2010: 20). Mulvey juga menegaskan posisinya ketika melihat aktris (Alice) dalam voyeuristic point of view and its object sebagai konstruksi "to be looked at" dan konsekuensi "gaze" tatapan (Mulvey, 2010:21). Konsep ini walaupun dinilai terlalu deterministik, nyatanya dapat memberikan efek yang berbeda ketika kamera mampu mematerialkan yang visual. Marks secara implisit menentang Mulvey, karena tidak bisa kegiatan menatap tersebut hanya berjalan satu arah, karena penonton juga dapat menangkap tekstur objek sesuai yang tengah digambarkan, artinya objek bisa hadir dan dirasakan secara material karena hilangnya kontrol yang sebatas visual saja (Marks, 2000:163)

Tekstur material yang ditangkap oleh indera (haptic) tentunya mampu menjelaskan mengapa kecanggihan kamera secara mimetis mampu memberikan sensasi yang tidak bisa dijabarkan mata penonton. Dimensi material yang hadir menjadi basis mengapa pada derajat tertentu penonton dapat menghela nafas menelan/mengecap ludah dan kemungkinan non optic lain karena secara tidak langsung indera peraba yang menubuh telah diaktifkan. Ini juga menjadi basis pengetahuan yang tidak selalu bersandar pada kemampuan kognitif tapi juga pengalaman atas tubuh.
Marks menyatakan bahwa tubuh juga merekam pengetahuan secara kultural, tubuh ada dalam posisi encoding history yang kemudai menyatakan bagaimana diri memahami dunia. Sehingga pada saat membicarakan persepsi, bahwa ada sekian barisan persepsi berikut partisipasinya di dalam dunia, sama seperti pikiran tentang bahwa feminitas sebagai kungkungan (Marks, 2000:152).

Tubuh juga merekam hal yang sifatnya kultural dimana selajutnya menginformasikan bagaimana tubuh mempersepsikan dunia. Persepsi yang menubuh merupakan pengalaman yang tidak bisa dilepaskan ketika berinteraksi dengan dunia. Tapi tidak serta merta pengalaman ini hadir begitu saja ketika adegan erotis yang ditampilkan oleh Mc Avoy dan Alice ditonton, karena kepekaan sensorik seseorang sangatlah beragam, namun Marks percaya bahwa ini bisa dilatih (Marks, 2000:23). Terlihat jelas bahwa aspek sinematografis ternyata mampu melampaui batas - batas audio visual, karena sensor yang menubuh bisa menangkap detail gambar secara lebih Sebenernya Mulvey justru memperkuat gagasan Marks, karena keaktifan menurut Mulvey bukan hadir begitu saja tanpa ada stimulus, dorongan dan arahan kamera yang sebenarnya mengatur aktris sebagai exhibitionist figure. Figur eksibisionis sebenarnya melegitimasi dirinya sebagai objek dari tatapan ataupun feminitas yang melampui hal tabu dan kenikmatan bagi pria, di lain sisi dia juga memproduksi ketidakstabilan kesadaran penonton wanita ketika dikaburkan memalui unsur komedi (Mulvey,2010:21). Artinya unsur komedi bisa mengkaburkan niat untuk eksibisinonis. Komedi yang mengacaukan, dapat dijelaskan secara jelas pada adegan keika James Mc Avoy salah mengucapkan 
kata "six" dan "sex". Kelucuan ini terjadi dirinya tengah sibuk menikmati lekuk tubuh Alice Eve yang duduk cantik sambil menatap menggoda.

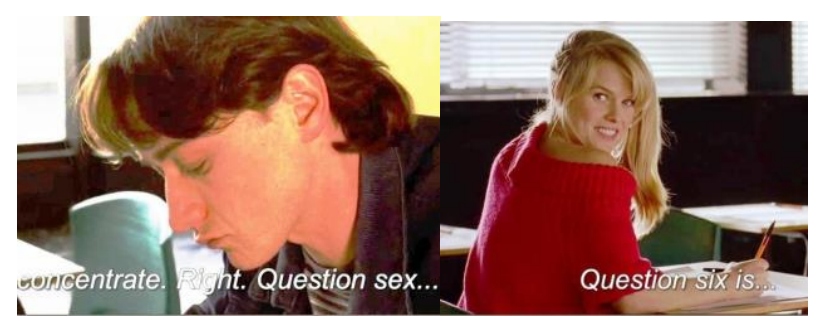

Kelucuan ini berlanjut ketika Alice meminta contekan, logika James menolak namun hasratnya berkata lain ketika mengingat senyum gadis cantik ini. Would you mind giving me the answers to three and five? Thanks//Cheating, She wants me to cheat. I can't do that... With pleasure. Three is potassium permanganate and five is Papua New Guinea (00:17:43,480 - 00:18:04,420)

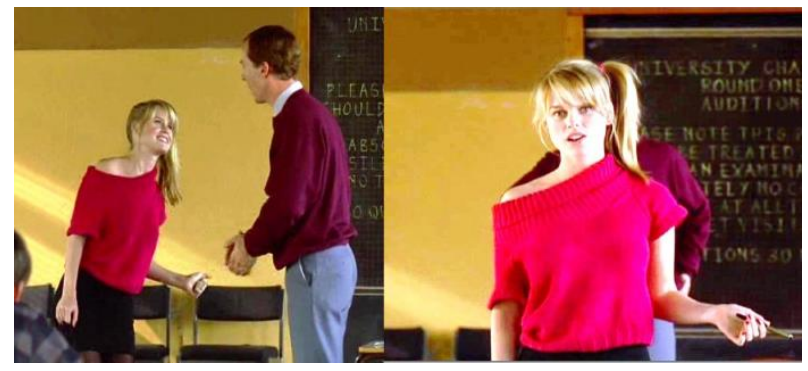

Kegiatan aktif eksibisionis terlihat dalam gambar dimana Alice berusaha melihatkan bagian tengkuknya dengan mendoyongkan badan guna mengambah kesan meggoda, ujung rambut yang menguntai kearah berlawanan juga menegaskan bagaimana dia memperlihatkan sensualitas terhadap lawan mainnya yang berkelamain pria. Pengambilan gambar berlanjut pada tahapan Alice Eve berjalan mendekat sembari memainkan lidahnya guna mengesankan kesan nakal dan menantang subjek, hal ini memungkinkan oposisi biner bekerja secara cermat dimana pria, dan penonton sebagai spectator/ male gaze berperilaku aktif dan aktris wanita cenderung passive dan eksibisionis (Mulvey,1996:62). Tetapi Marks melihat ini justru sebagai ruang potensial, untuk mengatasi dilema subjek-objek, yang ditatap dan yang menatap, dengan memberikan hemat yang berbeda ketika hal ini sampai pada wilayah haptic visuality karena haptic visuality membawa ketegangan antara yang menonton dengan yang gambar bergerak yang tengah dihadapinya. Ini disebabkan karena penonton menjadi rentan, vulnerable, kepada gambar yang membalik relasi tuan yang sangat melekat pada rezim optic (Marks, 2000:185)

Penekanan Marks melibatkan erotisme yang membuat subjek menjadi gagal menjadi tuan, karena pemahaman yang hanya melibatkan pandangan tenyata menyerah pada hal yang dicitrakan mammpu menjadi material dan melampaui rezim optic. Pandangan yang melampui kemampuan kognitif seolah lepas dari rezim penglihatan maka gugur pemahaman tentang gaze atas subjek dan objek (Marks, 2000:191).

Disinilah pemikiran Feminisme dan Haptic menemukan persimpangm jika voyeurisme dalam adegan erotis membuat manusia sebagai subjek (male gaze) aktif, dan aktris wanita cenderung pasif ternyata ada hal yang lepas dari pengamatan ketika pada derajat tertentu mata (gaze) tidak lagi menjadi referen utama melainkan (haptic visuality) dimana aktris bisa saja dalam dimensi ini menyentuh balik subjek dan menghasilkan interpenetrasi dan intersubjektivatas (Marks, 2000:183-184). Hemat ini juga menjadi kritik dikotomi subjek objek pada feminist theory terutama konsep tentang subjek yang terlalu mendewakan mata sebagai indera sebagai 
penentu satu - satunya dalam memahami film karena hubungan mutual bisa saja terjadi.

\section{KESIMPULAN}

Analisa adegan erotis dan eksibisionis seperti yang diutarakan oleh Mulvey dalam kerangka teori film feminisnya menekankan voyeurisme dan male gaze yang menilai aktris sebagai objek pasif dan patut diekslploitasi secara seksual sebagai sarana visual pleasure bagi pria yang dikonsepkan sebagi male gaze. Namun konsep ini nyatanya gagal ketika dipertemukan dengan haptic vision yang berakar dari pemikiran Deleuze untuk membongkar cara berfikir yang mendewakan mata sebagai satu satunya alat memahami film. Alice dalam film membuka pengalaman untuk menyentuh balik melalui teknik kamera yang mampu merekam apik setiap sudut kulitnya sehingga memunculkan pengalam visual menjadi material. Alice bukanlah visual pleasure, apalagi objek karena haptic visuality menjadi sarana untuk membuat penonton hanya sebagai pengamat tapi juga ikut berpartisipasi, atau dalam konteks ini ikut disentuh dengan cara dibangkitkan indera perabanya. Tubuh Alice yang direkam dalam deret shot memungkinkan adanya interpenetrasi indera dimana kaetgeori subjek - objek tidak lagi berlaku.

\section{DAFTAR PUSTAKA}

Anderson, Sandra et all. 2006. Dictionary of Media Studies. London: A \& C Black Publishers.

Deleuze, Gillez. 1989.Cinema 2: The Time Image. University of Minnesota Press. Minneapolis.
Deleuze, G. 2003. Francis Bacon: The logic of sensation. Minneapolis: University of Minnesota Press.

Marks, L.H. 2000. The Skin Of The Film: Intercultural Cinema, Embodiment And Senses. Durham \& London: Duke University Press.

Marks, L.H. 2002. Touch: Sensuoustheory And Multisensory Media. Minneapolis \& London: University of Minnesota press.

Mulvey, Laura. 2006. Death 24x a Second. London: Reaktion Books Ltd.

Mulvey, Laura. 2010. Reclaiming the Archive, Feminism and Film History.Michigan.

Wayne State University Press.

Mulvey, Laura. 1996. Fetishism And curiosity.Bloomington. Indiana University Press Turner, Graeme. 1999. Film as Social Practice. New York and London: Routledge.

\section{Info Film}

http://www.rottentomatoes.com/m/starter_for_ ten/ (diakses pada tanggal, 25/4/2015) 